\title{
PENGEMBANGAN MULTIMEDIA PEMBELAJARAN ANGKLUNG UNTUK SISWA SEKOLAH DASAR KELAS V
}

\author{
Afrizal Yudha Setiawan *, Susilo Pradoko \\ Universitas Negeri Yogyakarta. Jl. Colombo No. 1, Depok, Sleman 55281, Indonesia \\ * Corresponding Author. Email: afrizalpiano@gmail.com \\ Received: 22 Mei 2017; Revised: 18 Juni 2019; Accepted: 19 Juni 2019
}

\begin{abstract}
Abstrak
Penelitian dan pengembangan ini bertujuan untuk: (1) menghasilkan produk multimedia pembelajaran angklung; (2) menguji kelayakan produk; (3) mengetahui daya tarik produk; dan (4) mengetahui peningkatan hasil belajar siswa. Tahapan penelitian dan pengembangan ini meliputi analisis kebutuhan, perencanaan, perancangan, pengembangan, uji coba pemakaian, pementasan, dan produksi. Data dikumpulkan melalui angket, wawancara, observasi, dan tes. Data dianalisis dengan kualitatif deskriptif, kuantitatif deskriptif, dan uji beda. Hasil penelitian menunjukkan: (1) penilaian produk oleh ahli media mencapai skor 4,91; (2) penilaian produk oleh ahli materi mencapai skor 4,85; (3) penilaian produk oleh 2 guru mencapai rata-rata skor 4,73; (4) penilaian produk oleh 3 siswa mencapai rata-rata skor 4,24; (5) Penilaian produk pada uji beta mencapai rata-rata skor 4,56; (6) peningkatan hasil belajar aspek kognitif sebesar 30,00; dan (7) peningkatan hasil belajar aspek psikomotorik sebesar 12,96 . Terdapat perbedaan signifikan antara nilai rata-rata pretest dan posttest. Penggunaan multimedia pembelajaran angklung dapat meningkatkan hasil belajar siswa.
\end{abstract}

Kata kunci: Multimedia Pembelajaran, angklung, sekolah dasar

\section{DEVELOPING ANGKLUNG MULTIMEDIA FOR GRADE V STUDENTS OF PRIMARY $S C H O O L$}

This research and development study was aimed at: (1) producing angklung learning multimedia; (2) examining the appropriateness of the product; (3) investigating the attractiveness of the product; and (4) measuring students' improvement. The steps in this research and development study cover needs analysis, planning, designing, development, try out, performance, and production. The data were gathered by using questionnaire, interview, observation, and test. The data gathered was analyzed by using descriptive qualitative, descriptive quantitative, and T-test. The results of analysis showed that: (1) the score of the product by the media expert was 4,91; (2) the score of the product by the content expert was 4,85; (3) the average score of the product by 2 teacher was 4,73; (4) the average scores of the product by 3 students was 4,24; (5) the score of the product in beta test was 4,56; (6) students' cognitive improvement was 30,00; and (7) students' psychomotor improvement was 12,96. There was a significant difference between pretest and posttest scores. The use of angklung learning multimedia can improve students' achievement.

Keywords: Learning multimedia, angklung, primary school

doi) http://dx.doi.org/10.21831/jitp.v6i1.14082 


\section{Pendahuluan}

Pengajaran seni di sekolah merupakan salah satu komponen pengajaran yang secara terintegrasi mendukung pengembangan pribadi peserta didik seutuhnya, meningkatkan dan mengembangkan potensi rasa keindahan yang dimiliki oleh peserta didik, serta membentuk sikap disiplin, toleran, sosialisasi, dan demokrasi (Ardipal, 2015, pp. 19 - 20). Dengan demikian, pendidikan seni berkontribusi dalam mengembangkan potensi dan membentuk karakter peserta didik. Hal tersebut sesuai dengan tujuan yang tersirat dalam definisi pendidikan menurut Undang-Undang Republik Indonesia Nomor 20 Tahun 2003, bahwa pendidikan didefinisikan sebagai usaha sadar dan terencana untuk mewujudkan suasana belajar dan proses pembelajaran agar peserta didik secara aktif mengembangkan potensi dirinya untuk memiliki kekuatan spiritual keagamaan, pengendalian diri, kepribadian, kecerdasan, akhlak mulia, serta keterampilan yang diperlukan dirinya, masyarakat, bangsa, dan negara.

Pendidikan seni dalam kurikulum pendidikan di Indonesia memasukkan berbagai budaya yang ada di Indonesia sebagai bahan ajar dalam mata pelajaran seni budaya. Salah satu materi tersebut adalah musik nusantara. Materi pembelajaran musik nusantara tersebut adalah suatu bentuk upaya untuk memperkenalkan dan melestarikan produk kebudayaan bangsa Indonesia melalui pendidikan seni, termasuk dalam bidang seni musik. Hal tersebut sesuai dengan pendapat yang dikemukakan oleh Ardipal (2010, p. 2) bahwa mata pelajaran seni budaya memberikan sumbangan terhadap peserta didik agar berani dalam berkarya dan bangga terhadap budaya bangsanya sendiri. Adapun materi pembelajaran musik nusantara sudah menjadi bahan ajar di jenjang Sekolah Dasar.

Angklung adalah salah satu alat musik instrumental yang dapat digunakan dalam proses pembelajaran musik di
Sekolah Dasar, dan sesuai dengan materi pembelajaran musik nusantara. Pemerintah telah menetapkan angklung sebagai alat pendidikan musik berdasarkan Surat Keputusan Menteri Pendidikan dan Kebudayaan Republik Indonesia Nomor 082/1968 tentang Penetapan Angklung Sebagai Alat Musik Pendidikan. Angklung ditetapkan sebagai alat musik pendidikan, karena dalam permainan angklung terdapat hal-hal penting dan menonjol terutama dalam character building seperti kerjasama, gotong royong, disiplin, kecermatan, ketangkasan, dan tanggung jawab, yang kemudian dapat membangkitkan perhatian terhadap musik, menghidupkan musikalitas, mengembangkan rasa ritme, melodi, harmoni, dan lain-lain.

Meskipun angklung merupakan alat musik yang berasal dari Jawa Barat, namun alat musik ini tidak hanya digunakan dalam pembelajaran musik di sekolah-sekolah yang ada di Jawa Barat saja, melainkan di daerah-daerah lain seperti misalnya di SD Negeri 1 Fajar Mataram, Kecamatan Seputih Mataram, Kabupaten Lampung Tengah, Provinsi Lampung. Berdasarkan observasi pendahuluan yang dilakukan oleh peneliti, diperoleh data bahwa kegiatan pembelajaran angklung masih menggunakan metode yang sangat tradisional. Cara belajar angklung yang digunakan oleh guru adalah siswa memainkan angklung dengan menggunakan notasi yang tertulis di papan tulis, dan tanpa menggunakan musik iringan. Metode tersebut mengakibatkan siswa tidak dapat memainkan lagu dengan ritmis dan irama yang sesuai.

Berdasarkan wawancara pendahuluan yang dilakukan dengan guru kelas V SD Negeri 1 Fajar Mataram diperoleh informasi bahwa guru memiliki keterbatasan kompetensi dalam mengajarkan musik kepada siswa. Selain itu, dikatakan juga bahwa dalam mengajarkan musik nusantara, guru belum mengetahui metode yang tepat dan mudah digunakan untuk mengajar angklung. Hal tersebut dapat terlihat dari suasana kegiatan pembelajaran 
yang kurang interaktif. Selain itu, berbagai persoalan yang ditemui di lapangan pada observasi pendahuluan adalah ketertarikan siswa terhadap pembelajaran angklung masih kurang. Pengajaran angklung belum menggunakan media berupa alat musik untuk mengiringi siswa dalam memainkan alat musik angklung. Berdasarkan permasalahan tersebut, maka diperlukan suatu upaya untuk meningkatkan kualitas pembelajaran seni musik khususnya pada pembelajaran angklung, yang kemudian berdampak pada peningkatan hasil belajar siswa.

Berdasarkan permasalahan yang telah dipaparkan tersebut, maka perlu adanya upaya untuk meningkatkan kualitas pembelajaran seni musik di Sekolah Dasar. Salah satu upaya yang dapat dilakukan adalah dengan cara mengembangkan suatu media yang dapat digunakan dalam pembelajaran seni musik di sekolah dasar. Menurut Asyhar (2012, p. 8), media pembelajaran adalah segala sesuatu yang dapat digunakan untuk menyampaikan atau menyalurkan pesan dari suatu sumber secara terencana, sehingga terjadi suasana belajar yang kondusif dan penerimanya dapat melakukan aktivitas belajar secara efisien dan efektif.

Media pembelajaran seni musik yang dapat dikembangkan untuk siswa Sekolah Dasar adalah multimedia pembelajaran angklung, sebagai penunjang materi pembelajaran musik nusantara. Pengembangan multimedia pembelajaran angklung dapat membantu guru yang kurang memiliki kompetensi dalam bidang seni musik, dan memiliki kesulitan dalam melakukan pengajaran. Berdasarkan hasil wawancara yang dilakukan dengan guru kelas V SD Negeri 1 Fajar Mataram pada analisis kebutuhan, diperoleh data bahwa guru sangat membutuhkan media pembelajaran tersebut agar dapat melaksanakan kegiatan pembelajaran dengan lebih baik.

Di era globalisasi ini, perkembangan teknologi memberikan pengaruh yang cukup besar di berbagai sektor, termasuk dalam pendidikan. Salah satu manfaat dari perkembangan teknologi dalam dunia pendidikan adalah inovasi-inovasi media pembelajaran yang dapat bermanfaat sebagai alat bantu dalam proses pembelajaran, seperti multimedia pembelajaran. Inovasi media pembelajaran tersebut sebagian besar memanfaatkan teknologi komputer sebagai alat untuk mempermudah proses pembelajaran. Newby, Stepich, Lehman, Russell, dan Leftwich (2011, p. 49) mengatakan, "The computer is a powerful machine with a many different uses in education." Perangkat komputer memiliki banyak fungsi yang dapat digunakan dalam proses pembelajaran. Perangkat komputer dapat berperan sebagai guru, dan juga sebagai asisten bagi siswa.

Menurut Mayer (2009, p. 3), multimedia merujuk pada presentasi materi yang disajikan dengan menggunakan kata-kata dan gambar-gambar. Kata-kata dan gambar tersebut bertujuan untuk menarik perhatian siswa dan menciptakan suasana belajar menjadi lebih menarik dan memudahkan siswa untuk memahami materi pembelajaran, sebab siswa akan lebih mudah memahami materi jika disampaikan dalam kata-kata dan gambar-gambar, daripada hanya dalam kata-kata (Yu, Lai, Tsai, \& Chang, 2010, p. 161; Mayer, 2009, p. 3). Sebuah hasil penelitian menunjukkan bahwa pembelajaran berbasis multimedia dapat meningkatkan aktivitas, partisipasi, minat dan kreativitas siswa (Barzegar, Farjad, \& Hosseini, 2012, p. 1263).

Pengembangan multimedia pembelajaran angklung juga perlu ditunjang dengan penerapan metode pembelajaran angklung yang tepat. Dalam pembelajaran musik terdapat beberapa metode pembelajaran, salah satunya yang dapat diterapkan adalah metode pembelajaran Kodaly, yaitu metode pembelajaran yang didasarkan pada movable "do" atau "do" tidak tetap, dengan menggunakan gerakan tangan sebagai simbol dari masing-masing nada (Black, 1982, p. 3).

Berdasarkan hasil penelitian yang dilakukan oleh Supriadi (2006, p. 8) disebutkan bahwa salah satu cara dalam belajar 
angklung adalah dengan menggunakan simbol-simbol gerak tangan sebagai simbol nada yang ada pada tangga nada diatonis sesuai susunan nada, mulai dari nada "do" sampai "si". Dengan pendapat tersebut, simbol tangan Kodaly diaplikasikan dalam kegiatan pembelajaran angklung, dimana instruktur memberikan aba-aba mengenai nada yang dimainkan dengan menggunakan simbol tangan tersebut. Adapun metode pembelajaran seperti ini telah diterapkan di Sanggar Saung Angklung Udjo, Jawa Barat.

Berdasarkan beberapa pemaparan tersebut, maka untuk membantu dan memaksimalkan pembelajaran musik angklung di sekolah dasar, diperlukan pengembangan suatu media, yaitu multimedia pembelajaran angklung dengan mengadaptasi simbol tangan Kodaly sebagai metode pembelajaran. Multimedia pembelajaran ini dapat digunakan dalam proses pembelajaran secara praktik, memudahkan guru dalam menyampaikan materi, dan memudahkan proses pemahaman siswa terhadap materi bermain angklung. Selain itu, multimedia pembelajaran angklung juga dapat digunakan sebagai salah satu bentuk upaya pelestarian alat musik angklung kepada anak-anak khususnya di sekolah dasar.

\section{Metode Penelitian}

Jenis penelitian ini adalah penelitian pengembangan dengan Research and Development $(R \in \mathcal{E} D)$. Produk yang dikembangkan dalam penelitian ini berupa multimedia pembelajaran angklung, yang dikhususkan untuk siswa kelas V Sekolah Dasar. Penelitian ini mengadaptasi model penelitian dan pengembangan dari Borg dan Gall (1983), Alessi dan Trollip (2001), serta Pradoko dan Priyanto (2014, p. 90). Tahapan-tahapan dalam penelitian dan pengembangan ini meliputi analisis kebutuhan, perencanaan, perancangan, pengembangan, uji coba pemakaian, pementasan, dan produksi.
Penelitian dan pengembangan dilakukan pada bulan Juli 2016 sampai dengan Februari 2017. Uji coba produk dilaksanakan di SD Negeri 1 Fajar Mataram, Kecamatan Seputih Mataram, Kabupaten Lampung Tengah, Provinsi Lampung. Subjek yang terlibat dalam penelitian ini adalah 1 orang ahli media, 1 orang ahli materi, 2 orang guru, 3 siswa pada uji alfa, dan 21 siswa pada uji beta. Subjek yang terlibat dalam uji coba produk adalah 24 siswa kelas V di SD Negeri 1 Fajar Mataram. Dalam penelitian dan pengembangan ini terdapat 7 prosedur, yaitu: 1) analisis kebutuhan, meliputi studi lapangan dan studi pustaka; 2) perencanaan, dilakukan dengan mendefinisikan ruang lingkup, mengidentifikasi karakteristik siswa, membuat dokumen perencanaan, dan melakukan brainstroming; 3) perancangan, dilakukan dengan melakukan analisis konsep dan tugas, membuat flowchart dan storyboard, dan membuat scripts; 4) pengembangan, dilakukan dengan menyiapkan teks, menyiapkan dan memproduksi grafis, animasi, video, dan audio, serta menggabungkan bagian-bagian, uji alfa, revisi produk, uji beta, dan revisi akhir; 5) uji coba pemakaian, dengan melakukan pretest, melaksanakan kegiatan pembelajaran, pengamatan aktivitas belajar siswa, dan posttest; 6) pementasan; dan 7) produksi.

Teknik pengumpulan data yang digunakan dalam penelitian ini adalah angket, observasi, wawancara, dan tes. Fungsi angket dalam penelitian ini adalah untuk mengetahui kelebihan dan kekurangan dari produk yang dikembangkan, serta memberikan penilaian secara objektif terhadap produk tersebut. Terdapat 4 macam angket dalam penelitian ini, yaitu: angket untuk ahli media, angket untuk ahli materi, angket untuk guru, dan angket untuk siswa. Teknik wawancara digunakan pada saat melakukan analisis kebutuhan. Wawancara pada analisis kebutuhan dilakukan dengan 2 informan, yaitu pengawas dan guru. Bentuk wawancara yang digunakan adalah wawancara tidak terstruktur. Observasi digunakan dalam 
beberapa bentuk kegiatan. Pertama, pada saat analisis kebutuhan, yaitu meliputi observasi kondisi sekolah dan kondisi siswa. Observasi kedua dilakukan pada uji coba produk, yaitu pada saat produk digunakan dalam kegiatan pembelajaran. Instrumen tes digunakan pada pelaksanaan pretest dan posttest. Terdapat 2 bentuk tes, yaitu tes kognitif dan psikomotorik. Instrumen tes kognitif berupa 10 soal pilihan ganda dengan 4 alternatif jawaban, sedangkan instrumen tes psikomotorik berupa lembar penilaian keterampilan.

Data yang diperoleh melalui observasi dan wawancara adalah data-data berupa saran dan komentar dari ahli materi dan ahli media, tanggapan siswa, hasil wawancara dengan pengawas dan guru, serta catatan hasil observasi. Data-data tersebut dianalisis dengan menggunakan pendekatan kualitatif deskriptif, dan dilakukan penarikan kesimpulan. Data hasil penilaian produk yang berupa skor penilaian terhadap kualitas produk yang telah dikembangkan dianalisis dengan menggunakan pendekatan kuantitatif deskriptif. Rentang nilai yang digunakan adalah skala 5 (lima). Skor yang telah diperoleh dijumlahkan dan dihitung ratarata perolehan skor dengan rumus yang dapat dilihat pada Rumus 1.

$$
X i=\frac{\sum X}{n}
$$

$\begin{array}{ll}X i & =\text { skor rata-rata } \\ \sum_{n} X & =\text { jumlah skor } \\ & =\text { jumlah butir pernyataan }\end{array}$

Rata-rata skor yang telah diperoleh, kemudian dikonversikan menjadi data kualitatif skala lima, dengan acuan rumus sebagaimana pada Tabel 1. Dalam penelitian ini, ditetapkan nilai kelayakan produk minimal dengan kategori "Baik", sebagai hasil penilaian dari ahli media, ahli materi, guru dan siswa. Jika hasil akhir penilaian dari ketiga komponen penilai tersebut memperoleh nilai "Baik", maka produk hasil pengembangan tersebut sudah dianggap layak digunakan sebagai media pembelajaran.

Tabel 1. Konversi Data Kuantitatif ke Data Kualitatif dengan Skala Lima

\begin{tabular}{lcc}
\hline \multicolumn{1}{c}{ Rumus } & Perhitungan & Kriteria \\
\hline$X>X_{i}+1,80 S B_{i}$ & $X>4,21$ & Sangat \\
& & Baik \\
$X_{i}+0,60 S B_{i}<X \leq X i+1,80 S_{i}$ & $3,40<X \leq 4,2$ & Baik \\
$X_{i}-1,80 S B_{i}<X \leq X i+0,60 S B_{i}$ & $2,60<X \leq 3,40$ & Cukup \\
$X_{i}-1,80 S B_{i}<X \leq X i-0,60 S B_{i}$ & $1,79<X \leq 2,60$ & Kurang \\
$X \leq X_{i}-1,80 S B_{i}$ & $X \leq 1,79$ & Sangat \\
& & Kurang \\
\hline
\end{tabular}

Keterangan:

Rerata skor ideal $(X i)$

$X i=1 / 2$ (skor maksimal ideal + skor minimal ideal)

Simpangan baku skor ideal $\left(S B_{i}\right)$

$S B_{i}=1 / 6$ (skor maskmial ideal - skor minimal ideal) $X=$ Skor empiris

Selain itu, untuk mencari skor ratarata (rerata skor) dalam memberikan penilaian terhadap produk yang melibatkan subjek lebih dari satu menggunakan rumus yang dapat dilihat pada Rumus 2 .

$$
X i=\frac{\sum X}{n}
$$

$$
\begin{array}{ll}
X i & =\text { skor rata-rata } \\
\sum X & =\text { jumlah skor } \\
n & =\text { jumlah responden }
\end{array}
$$

Data hasil belajar siswa berupa nilai yang diperoleh dalam tahapan pretest dan posttest. Penentuan kriteria nilai yang diperoleh siswa pada pretest dan posttest dapat dilihat pada Tabel 2. Selain itu, untuk mengetahui adanya perbedaan yang signifikan antara hasil pretest dan posttest dilakukan analisis uji beda dengan menggunakan Paired-Samples T Test. Pengambilan keputusan didasarkan pada perolehan nilai signifikansi berdasarkan hasil analisis. Jika nilai signifikansi yang diperoleh kurang dari 0,05, maka terdapat perbedaan yang signifikan antara hasil pretest dengan posttest. Namun, untuk melakukan analisis uji beda tersebut terlebih dahulu dilakukan uji prasyarat analisis, yakni uji normalitas dan homogenitas. Keseluruhan analisis 
tersebut dilakukan dengan menggunakan bantuan software SPSS Statistics 19.

Tabel 2. Hasil Penilaian Produk pada Uji Alfa

\begin{tabular}{ccc}
\hline No. & Rentang Nilai & Kriteria \\
\hline 1 & $80-100$ & Sangat Baik \\
2 & $70-79$ & Baik \\
3 & $60-69$ & Cukup \\
4 & $45-59$ & Kurang \\
5 & $<45$ & Sangat Kurang \\
\hline
\end{tabular}

Analisis uji beda bertujuan untuk mengetahui apakah terdapat perbedaan yang signifikan antara nilai pretest ketika siswa belum menggunakan produk multimedia pembelajaran angklung, dengan nilai posttest ketika siswa sudah belajar menggunakan produk multimedia pembelajaran angklung.

\section{Hasil dan Pembahasan}

\section{Hasil Pengembangan}

Pengembangan produk awal multimedia pembelajaran angklung dilakukan berdasarkan hasil analisis kebutuhan, melalui studi lapangan berupa observasi, wawancara, dan pengisian angket oleh siswa, serta studi pustaka terkait dengan Standar Kompetensi (SK) dan Kompetensi Dasar (KD) pada mata pelajaran Seni Budaya dan Keterampilan (SBK) bidang seni musik. Berdasarkan hasil analisis kebutuhan tersebut diperoleh kesimpulan bahwa multimedia pembelajaran angklung sangat dibutuhkan sebagai media pembelajaran untuk mempermudah guru dalam mengajar. Berdasarkan pengisian angket juga diperoleh kesimpulan bahwa siswa menunjukkan respon yang positif terhadap pengembangan produk tersebut. Selain itu, pengembangan multimedia pembelajaran angklung didasarkan pada salah satu SK dan KD, yaitu "4.1. Memainkan alat musik ritmis atau melodis sederhana dalam bentuk ansambel sejenis."

Setelah melakukan analisis kebutuhan, tahapan pengembangan dilanjutkan dengan melakukan perencanaan. Dalam tahapan perencanaan dilakukan pendifinisan ruang lingkup, berupa penetapan tujuan pembelajaran dan pembatasan materi yang dituangkan ke dalam produk. Perumusan tujuan pembelajaran berorientasi pada pencapaian hasil belajar dalam aspek kognitif, psikomotorik, dan keterampilan, sebagai berikut: (1) memberikan wawasan dan pengetahuan siswa tentang alat musik angklung; (2) melatih dan menumbuhkan keterampilan siswa dalam bermain angklung; dan (3) menanamkan sikap-sikap positif dalam diri siswa melalui kegiatan bermain angklung, seperti sikap kerjasama, saling menghargai, disiplin, dan tanggung jawab.

Pembatasan materi ditentukan berdasarkan tingkat kemampuan, tingkat kebutuhan, dan gaya belajar siswa sebagai subjek belajar. Materi dalam produk dibatasi pada penggunaan alat musik angklung melodis sarinande 1 oktaf dan penggunaan simbol tangan Kodaly sebagai metode dalam memainkan angklung secara bersama-sama. Terdapat 6 (enam) materi pokok dalam produk multimedia angklung yang dikembangkan, yaitu: video pertunjukan angklung, mengenal angklung melodis, cara membunyikan angklung, metode simbol tangan Kodaly, memainkan tangga nada, dan memainkan lagu. Setelah melakukan penetapan tujuan dan pembatasan materi, pengembangan produk dilanjutkan dengan pembuatan dokumen perencanaan. Tahapan ini menghasilkan skema produk, draft materi pembelajaran, dan draft isi produk. Hasil dokumen tersebut kemudian didiskusikan dengan guru, dosen pembimbing, dan tim produksi, serta dilakukan revisi sesuai saran.

Tahapan pengembangan dilanjutkan dengan merancang produk. Dalam tahapan ini dihasilkan sebuah flowchart dan storyboard, serta script yang dibutuhkan dalam memproduksi audio dan video. Setelah rancangan produk selesai dilaksanakan, tahapan dilanjutkan dengan memproduksi dan menggabungkan komponenkomponen ke dalam produk, seperti audio, 
video, materi produk, dan grafis. Proses produksi dilakukan dengan menggunakan beberapa software sesuai dengan fungsinya. Adapun salah satu hasil pengembangan produk dapat dilihat dalam Gambar 1.

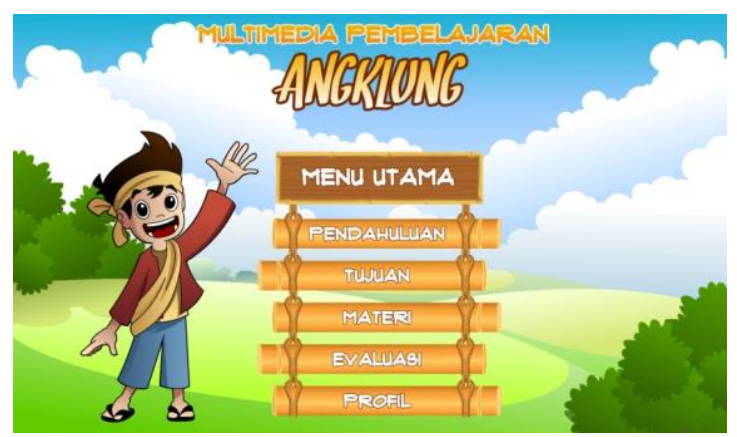

Gambar 1. Hasil Pengembangan Produk (Tampilan Menu Utama)

Hasil Penilaian Produk

Penilaian produk dilakukan dengan uji alfa dan uji beta. Uji alfa melibatkan 1 orang ahli media, 1 orang ahli materi, 2 guru, dan 3 siswa, sedangkan uji beta melibatkan 21 siswa. Hasil dari penilaian tersebut dapat dilihat dalam Tabel 3 dan 4 .

Tabel 3. Hasil Penilaian Produk pada Uji Alfa

\begin{tabular}{ccc}
\hline $\begin{array}{c}\text { Subjek/ } \\
\text { Penilai }\end{array}$ & Skor & Kriteria \\
\hline Ahli Media & 4,91 & Sangat Baik \\
Ahli Materi & 4,85 & Sangat Baik \\
2 Guru & 4,73 & Sangat Baik \\
3 Siswa & 4,24 & Sangat Baik \\
\hline
\end{tabular}

Berdasarkan Tabel 3 dan 4, dapat disimpulkan bahwa kelayakan dan kualitas produk dari segi media dan materi sangat baik. Hal tersebut ditunjukkan dengan peroleh skor penilaian oleh ahli media sebesar 4,91 dan ahli materi sebesar 4,85. Kedua skor tersebut berada pada kriteria "Sangat Baik". Selain itu, produk tersebut juga memiliki daya tarik yang sangat baik. Hal tersebut ditunjukkan dengan perolehan skor penilaian produk oleh guru sebesar 4,73 dan perolehan skor penilaian produk oleh 3 siswa pada uji alfa sebesar 4,24. Kedua skor tersebut berada pada kriteria sangat baik. Adapun penialain produk pada uji beta dengan melibatkan 21 siswa sebagai responden juga memperoleh rata-rata skor dengan kriteria "Sangat Baik" yakni sebesar 4,56. Dengan demikian, dapat disimpulkan bahwa produk multimedia pembelajaran angklung memiliki kualitas yang sangat baik, dari segi media, materi, dan daya tarik produk.

Tabel 4. Hasil Penilaian Produk pada Uji Beta

\begin{tabular}{ccc}
\hline $\begin{array}{c}\text { Subjek/ } \\
\text { Penilai }\end{array}$ & $\begin{array}{c}\text { Rata-rata } \\
\text { Skor }\end{array}$ & Kriteria \\
\hline 21 siswa & 4,56 & Sangat Baik \\
\hline
\end{tabular}

Hasil Uji Coba Produk

Pretest (tes awal) dilakukan sebelum produk multimedia pembelajaran angklung digunakan dalam proses pembelajaran. Pretest dilakukan untuk mengukur kemampuan awal siswa baik dari aspek kognitif, dan psikomotorik. Pada pretest aspek kognitif, diperoleh nilai rata-rata sebesar 52,5. Nilai tersebut berada pada kriteria "Kurang". Pada pretest aspek psikomotorik diperoleh nilai rata-rata sebesar 53,77. Nilai tersebut berada pada kriteria "Kurang". Berdasarkan hasil pretest tersebut dapat disimpulkan bahwa kemampuan awal yang dimiliki oleh siswa baik dari aspek kognitif dan psikomotorik masih sangat rendah. Oleh sebab itu, perlu adanya tindakan untuk meningkatkan hasil belajar tersebut. Tindakan tersebut dilakukan melalui uji coba produk dalam kegiatan pembelajaran.

Posttest dilakukan setelah kegiatan pembelajaran (uji coba produk) selesai dilaksanakan. Hasil posttest menunjukkan adanya peningkatan hasil belajar siswa baik dari aspek kognitif maupun psikomotorik. Perolehan rata-rata nilai aspek kognitif sebesar 82,5. Nilai tersebut berada pada kriteria "Sangat Baik", dan peroleh rata-rata nilai aspek psikomotorik sebesar 66,73. Nilai tersebut berada pada kriteria "Cukup".

Pengamatan dilakukan pada saat proses pembelajaran sedang berlangsung. 
Kegiatan pengamatan bertujuan untuk menggali informasi mengenai aktivitas belajar siswa pada saat menggunakan produk multimedia pembelajaran angklung dalam proses belajar mengajar. Hasil pengamatan menunjukkan bahwa: (1) siswa mengikuti kegiatan pembelajaran dengan tertib dan sungguh-sungguh; (2) siswa terlihat antusias dalam proses pembelajaran dengan penerapan multimedia pembelajaran angklung, terutama pada aktivitas pembelajaran secara praktik; (3) siswa tidak mengalami kesulitan dalam memahami materi, namun tempo pada lagu "Kasih Ibu" dirasa terlalu cepat, sehingga diperlukan revisi terhadap lagu tersebut; (4) siswa dapat memahami penggunaan metode simbol tangan Kodaly dengan baik; (5) kegiatan pembelajaran yang telah dilaksanakan dapat menciptakan rasa kebersamaan, kekompakan dan tanggungjawab yang baik antar siswa.

Uji normalitas dilakukan pada data nilai pretest dan posttest baik dari nilai aspek kognitif maupun psikomotorik. Hasil analisis uji normalitas pada data nilai pretest dan posttest dapat dilihat dalam tabel 5 dan 6.

Tabel 5. Hasil Uji Normalitas Nilai Pretest dan Posttest Aspek Kognitif

\begin{tabular}{cccc}
\hline Nilai & Sig. & Kesimpulan & Keterangan \\
\hline Pretest & 0,070 & Normal & $0,070>0,05$ \\
Posttest & 0,058 & Normal & $0,058>0,05$ \\
\hline
\end{tabular}

Tabel 6. Hasil Uji Normalitas Nilai Pretest dan Posttest Aspek Psikomotorik

\begin{tabular}{cccc}
\hline Nilai & Sig. & Kesimpulan & Keterangan \\
\hline Pretest & 0,117 & Normal & $0,117>0,05$ \\
Posttest & 0,538 & Normal & $0,538>0,05$ \\
\hline
\end{tabular}

Berdasarkan hasil analisis tersebut, dapat disimpulkan bahwa seluruh data nilai pretest dan posttest, baik dari aspek kognitif maupun psikomotorik, berdistribusi normal. Hal tersebut ditunjukkan dengan perolehan nilai signifikansi lebih besar dari 0,05. Hasil analisis uji homogenitas pada data nilai pretest-posttest aspek kognitif dan psikomotorik dapat dilihat pada Tabel 7.

Tabel 7. Hasil Uji Homogenitas Nilai Pretest-Posttest Aspek Kognitif dan Psikomotorik

\begin{tabular}{cccc}
\hline Nilai & Sig. & Kesimpulan & Keterangan \\
\hline Kognitif & 0,917 & Homogen & $0,917>0,05$ \\
Psikomotorik & 0,830 & Homogen & $0,830>0,05$ \\
\hline
\end{tabular}

Berdasarkan hasil analisis tersebut, dapat disimpulkan bahwa seluruh data nilai pretest dan posttest, baik dari aspek kognitif maupun psikomotorik, berasal dari kelompok data yang homogen. Hal tersebut ditunjukkan dengan perolehan nilai signifikansi lebih besar dari 0,05.

Tabel 8. Hasil Uji Beda Nilai PretestPosttest Aspek Kognitif dan Psikomotorik

\begin{tabular}{cccc}
\hline Nilai & Sig. & Kesimpulan & Keterangan \\
\hline Kognitif & 0,000 & Signifikan & $0,000<0,05$ \\
Psikomotorik & 0,000 & Signifikan & $0,000<0,05$ \\
\hline
\end{tabular}

Hasil uji beda disajikan dalam tabel 8, berdasarkan hasil analisis tersebut, diperoleh nilai signifikansi pada aspek kognitif sebesar 0,000 dan pada aspek psikomotorik sebesar 0,000. Kedua nilai tersebut lebih kecil dari $0,05(0,000<0,05)$. Dengan demikian, dapat disimpulkan bahwa terdapat perbedaan yang signifikan antara nilai pretest ketika siswa belum menggunakan produk multimedia pembelajaran angklung dengan nilai posttest ketika siswa sudah menggunakan multimedia pembelajaran angklung.

Tabel 9. Nilai Rata-rata Pretest dan Posttest

\begin{tabular}{cccc}
\hline Nilai & Pretest & Posttest & Peningkatan \\
\hline Kognitif & 52,50 & 82,50 & 30,00 \\
Psikomotorik & 53,77 & 66,73 & 12,96 \\
\hline
\end{tabular}

Peningkatan hasil belajar siswa dapat ditunjukkan dengan adanya peningkatan nilai rata-rata pada pretest dan posttest. Adapun peningkatan nilai rata-rata tersebut dapat dilihat dalam Tabel 9 dan Gambar 2. 


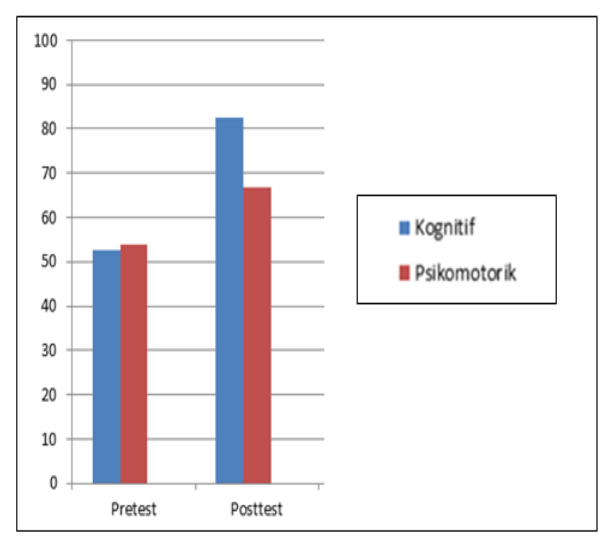

Gambar 2. Diagram Nilai Rata-rata Pretest dan Posttest.

Berdasarkan Tabel 9 dan Gambar 2, dapat dikatakan bahwa terdapat peningkatan hasil belajar siswa baik dari aspek kognitif dan psikomotorik. Nilai rata-rata pada aspek kognitif meningkat sebesar 30,00 dan pada aspek kognitif meningkat sebesar 12,96. Berdasarkan analisis secara keseluruhan, dapat disimpulkan bahwa penggunaan multimedia pembelajaran angklung dalam proses pembelajaran dapat meningkatkan hasil belajar siswa.

\section{Kajian Produk Akhir}

Produk yang dihasilkan dalam pengembangan multimedia pembelajaran angklung adalah $\mathrm{CD}$ pembelajaran yang dapat digunakan dalam kegiatan pembelajaran angklung. CD pembelajaran yang dihasilkan adalah produk akhir yang telah dikembangkan sesuai dengan prosedur pengembangan. Adapun produk tersebut telah dinilai oleh ahli media, ahli materi, guru, dan siswa. Seluruh penilaian produk berada pada kriteria "Sangat Baik".

Penggunaan produk multimedia pembelajaran angklung dapat meningkatkan hasil belajar siswa. Hal tersebut ditunjukkan dengan adanya perbedaan yang signifikan antara nilai pretest ketika siswa belum menggunakan produk multimedia pembelajaran angklung, dengan nilai posttest ketika siswa sudah belajar menggunakan multimedia pembelajaran angklung. Peningkatan hasil belajar terjadi pada aspek kognitif maupun psikomotorik. Pada aspek kognitif terjadi peningkatan nilai rata-rata sebesar 30,00 dan pada aspek psikomotorik terjadi peningkatan nilai ratarata sebesar 12,96.

Dengan menggunakan produk multimedia pembelajaran angklung, siswa dapat terlibat dalam lingkungan belajar yang memaksimalkan aktivitas belajar secara praktik, yang kemudian berdampak pada pengembangan kemampuan siswa pada aspek kognitif, maupun psikomotorik. Mark \& Madura (2010, p.5) mengatakan bahwa "Music is good for children intellectuality and physically". Berdasarkan pendapat tersebut, aktivitas bermusik secara praktik dapat memaksimalkan perkembangan siswa baik dari aspek kognitif, maupun psikomtorik. Adapun multimedia pembelajaran angklung yang telah dikembangkan memberikan kesempatan belajar kepada siswa untuk terlibat dalam aktivitas bermusik secara praktik. Dengan demikian, penggunaan multimedia pembelajaran tersebut berdampak pada perkembangan kognitif dan psikomotorik siswa.

Penggunaan multimedia pembelajaran angklung juga dapat memberikan dampak perubahan tingkah laku siswa dalam ranah afektif. Ozgul (2009, p. 117) mengatakan "Music activities should encourage students to become cooperative and peaceloving citizens instilled with civic pride, tolerance for other cultures, sensitivity and open-mindedness to the other fine arts as well as confidence in themselves as musicians." Pendapat tersebut mengisyaratkan bahwa aktivitas bermain musik dapat memberikan ruang bagi siswa untuk menjadi individu yang mampu bekerja sama, memiki sikap toleransi dan kepekaan rasa, serta memiliki pikiran yang terbuka terhadap karya seni yang lainnya. Produk multimedia pembelajaran angklung yang dikembangkan berisi tentang materi pembelajaran yang dirancang dalam bentuk aktivitas bermain musik secara bersama-sama. Dengan demikian, sikap-sikap positif seperti kerjasama, toleransi, dan kepekasaan rasa dapat ter- 
bangun dalam diri siswa melalui aktivitas pembelajaran tersebut.

Produk multimedia pembelajaran ini merupakan alternatif untuk mengatasi keterbatasan kemampuan guru di Sekolah Dasar dalam mengajar bidang studi seni musik, serta Seni Budaya dan Keterampilan (SBK), karena dalam produk multimedia pembelajaran yang dikembangkan terdapat berbagai komponen yang terintegrasi dan dapat memudahkan guru dalam mengajar. Hal tersebut sesuai dengan pendapat Reddi \& Mishra (2003, p. 4); Newby, Stepich, Lehman, Russell, \& Leftwich, (2011, p. 128) bahwa multimedia merupakan bentuk integrasi dari beberapa media, seperti teks, gambar/grafis, audio, animasi, video, objek nyata (real object), dan objek tiruan (models). Media-media tersebut menjadi satu kesatuan yang sinergis dan saling berhubungan, sehingga dapat memberikan manfaat yang lebih bagi pengguna (user). Guru merupakan salah satu pengguna (user) yang menggunakan multimedia tersebut. Adapun salah satu manfaat penggunaan multimedia tersebut bagi guru adalah materi pembelajaran dapat disampaikan dengan lebih mudah.

Pengajaran dengan menggunakan produk tersebut juga dapat menciptakan suasana pembelajaran yang menarik dan menyenangkan bagi siswa. Hal ini dapat memberikan dampak pada minat dan motivasi siswa dalam belajar. Hal tersebut sesuai dengan pendapat yang dikemukakan oleh Mayer (2009, p. 3), bahwa kata-kata dan gambar dalam sajian multimedia pembelajaran bertujuan untuk menarik perhatian siswa dan menciptakan suasana belajar menjadi lebih menarik dan memudahkan siswa untuk memahami materi pembelajaran, sebab siswa (orang yang sedang belajar) akan lebih mudah memahami materi jika disampaikan dalam kata-kata dan gambar-gambar, daripada hanya dalam kata-kata. Dengan demikian, kegiatan pembelajaran menggunakan multimedia dapat memberikan kesan yang menarik dan menyenangkan bagi siswa.

\section{Simpulan}

Berdasarkan hasil penelitian dan pengembangan yang telah dilakukan, dapat disimpulkan beberapa hal sebagai berikut: (1) Produk akhir multimedia pembelajaran angklung berisi tentang materi tentang angklung, latihan simbol tangan Kodaly, dan lagu-lagu yang dapat digunakan dalam bermain angklung secara ansambel, disertai dengan instruktur yang memberikan abaaba menggunakan simbol tangan Kodaly; (2) Kelayakan dan kualitas produk multimedia pembelajaran angklung sangat baik, dengan perolehan skor sebesar 4,91 pada penilaian ahli media, dan 4,85 pada penilaian ahli materi; (3) daya tarik produk berdasarkan penilaian pengguna menunjukkan kriteria sangat baik, dengan perolehan skor 4,73 pada penilaian guru, 4,24 pada penilaian siswa uji alfa, dan 4,56 pada penilaian siswa uji beta; (4) Penggunaan multimedia pembelajaran angklung dapat meningkatkan hasil belajar siswa, baik dari aspek kognitif, maupun psikomotorik. Terdapat perbedaan yang signifikan antara nilai rata-rata pretest dan posttest dengan nilai signifikansi 0,000. Peningkatan nilai rata-rata pada aspek kognitif adalah sebesar 30,00 dan peningkatan nilai rata-rata pada aspek psikomotorik adalah sebesar 12,96.

\section{Daftar Pustaka}

Alessi, S. M., \& Trollip, S. R. (2001). Multimedia for learning: methods and development, $3^{\text {rd }}$ edition. A Pearson Education Company.

Ardipal. (2015). Model pengembangan karakter melalui pendidikan seni di Sekolah Dasar. Jurnal Humanus, 14(1), 17-23. doi:https://doi.org/10.24036/jh.v1 4 i1.5397.

. (2010). Kurikulum pendidikan seni budaya yang ideal bagi peserta didik di masa depan. Jurnal Bahasa dan Seni, 11(1), 1-10. doi:https:/ / doi.org/10.24036/ kom posisi.v11i1.69. 
Asyhar, R. (2012). Kreatif mengembangkan media pembelajaran. Jakarta: Referensi Jakarta.

Barzegar, N., Farjad, S., \& Hosseini, N. (2012). The effect of teaching model based on multimedia and network on the student learning (case study: guidance schools in Iran). Procedia Social and Behavioral Sciences, 47, 1263-1267.

doi:https://doi.org/10.1016/j.sbspr o.2012.06.809.

Black, S. (1982). The application of the Kodaly method to instrumental music education. University of Richmond, Virginia.

Borg, W. R., \& Gall, M. D. (1989). Educational research: an introduction, $5^{\text {th }}$ edition. New York: Longman.

Mark, M. L., \& Madura, P. (2009). Music education in your hands: an introduction for future teacher, $1^{\text {st }}$ edition. New York: Routledge.

Mayer, R. E. (2009). Multimedia learning, 2nd Edition. New York: Cambridge University Press.

Newby, T. J., Stepich, D. A., Lehman, J., Russell, J. D., \& Ottenbreit-Leftwich, A. (2011). Educational technology for teaching and learning, $4^{\text {th }}$ edition. Boston: Pearson.

Ozgul, I. (2009). An analysis of the elementary school music teaching course in Turkey. International Journal of Music Education, 27(2), 116-127. doi:https://doi.org/10.1177/025576 1409102321.

Pradoko, S., \& Priyanto, W. P. (2014). Rancang bangun musik angklung model SATB, dasar aransemen model orchestra. Imaji, 14(1), 90-97. doi:https://doi.org/10.21831/imaji. v14i1.9538.

Reddi, U. V., \& Mishra, S. (2003). Educational multimedia: a handbook for teacher-developers. New Delhi: CEMCA.

Supriadi, D. (2006). Model pembelajaran angklung sunda kreasi di Sanggar
Saung Angklung Udjo, Nglagena, Padasuka, Bandung Jawa Barat. Harmonia Jurnal Pengetahuan dan Pemikiran Seni, 7(3), 1-14. doi:https://doi.org/10.15294/harm onia.v7i3.742.

Yu, P. T., Lai, Y. S., Tsai, H. H., \& Chang, Y. H. (2010). Using a multimodal learning system to support music Instruction. Journal of Educational Technology \& Society, 13(3), 151-162. doi:https://doi.org/10.2307/jeduct echsoci.13.3.151. 